\title{
Lithuanians' perceptions of vaccination and their sources of information: a literature review
}

\author{
Valinciute, Auste ; Schäfer, Mike S
}

\begin{abstract}
Objective: Attitudes towards vaccination are important drivers of vaccination decisions and behavior. But researchers have pointed to the shortage of such studies on Eastern Europe. Methods: A literature review of 14 survey studies was conducted. Results: The review showed that Lithuanians' attitudes towards vaccines appear to be volatile with considerable discrepancy between views about the importance of vaccines and their perceived effectiveness and safety. Perceptions of vaccine risks are high, with Lithuanians challenging both specific vaccines (children's, flu) and vaccination in general. Lithuanians' perceptions of vaccine importance are among the lowest in the EU (24th out of 28 countries). Conclusions: Lithuanians do not entirely reject vaccines, but many are worried about their health impact. More studies are needed to explore vaccine perceptions in Lithuania and potential factors shaping those, like media representations.
\end{abstract}

DOI: https://doi.org/10.1007/s00038-020-01389-0

Posted at the Zurich Open Repository and Archive, University of Zurich

ZORA URL: https://doi.org/10.5167/uzh-197143

Journal Article

Accepted Version

Originally published at:

Valinciute, Auste; Schäfer, Mike S (2020). Lithuanians' perceptions of vaccination and their sources of information: a literature review. International Journal of Public Health, 65(6):981-991.

DOI: https://doi.org/10.1007/s00038-020-01389-0 


\section{Lithuanians' perceptions of vaccination and their sources of 2 information: a literature review}

Abstract

Objective: Attitudes towards vaccination are important drivers of vaccination decisions and behavior. But researchers have pointed to the shortage of such studies on Eastern Europe. Methods: A literature review of 14 survey studies was conducted. Results: The review showed that Lithuanians' attitudes towards vaccines appear to be volatile with considerable discrepancy between views about the importance of vaccines and their perceived effectiveness and safety. Perceptions of vaccine risks are high, with Lithuanians challenging both specific vaccines (children's, flu) and vaccination in general. Lithuanians' perceptions of vaccine importance are among the lowest in the EU $\left(24^{\text {th }}\right.$ out of 28 countries). Conclusions: Lithuanians do not entirely reject vaccines, but many are worried about their health impact. More studies are needed to explore vaccine perceptions in Lithuania and potential factors shaping those, like media representations.

Keywords: public attitudes; health communication; vaccination; Lithuania; survey studies;

\section{Introduction}

Vaccines are one of the most successful disease preventive measures in the history of public health. In recent years, however, a sizable number of people have become hesitant about vaccination - a development tied to a rise of several diseases. For example, continuous outbreaks of measles have been linked to vaccine hesitancy (Lane et al., 2018; Thornton, 2019; WHO, 2019). Therefore, scholars have investigated the public's knowledge, attitudes and beliefs about vaccines, which are known to influence vaccine acceptance and behaviors (WHO, 2014; Dubé, 2013). But these efforts have not focused on all countries equally. A 2014 review of empirical research on attitudes towards vaccination in Europe noted "a paucity of papers from Eastern Europe" (Yaqub, 2014). We aim to fill this gap, providing a review of scholarly literature on public perceptions about vaccines in Lithuania.

\section{The Case of Lithuania}

Lithuania is a northeastern European country, which gained independence in 1990 after several decades of occupation by the Soviet Union. Afterwards, Lithuania reintegrated into Western Europe, joined the World Trade Organization, NATO and the European Union and entered the Eurozone in 2015. It has a strong economy and a rapidly growing innovation sector (OECD, 2018a) and is among the EU's most educated countries with one of the highest percentages of adults (over $90 \%$ of 25-64 year olds) with upper secondary education (Eurostat, 2018). 
The Lithuanian health care system is based on a national insurance model, with the government spending 6.5\% of GDP on health services (OECD, 2018b). With regards to vaccines, the Lithuanian health care system fully compensates children's immunization for 14 diseases including measles, polio and rotavirus infections (ULAC, 2019).

Despite the availability of vaccines and easy access via pediatricians, monitoring of children's vaccination trends in Lithuania between 2003 and 2017 showed a statistically significant decline in the coverage for tuberculosis BCG, hepatitis B and mumps, measles and rubella vaccines (Šebeliauskaitė and Čaplinskas, 2018). Decreasing vaccination coverage was partly followed by outbreaks of vaccine preventable diseases like measles (figure 1) (ULACa). In 2019 Lithuania reported over 800 cases of measles, making it the single biggest outbreak in the last decade (ULACb). Among European countries, Lithuania had one of the largest numbers of measles cases per 1 million population (ECDC, 2019). This makes Lithuania an important case study for understanding and tackling public rejection of vaccination in the European context and beyond.

(Insert figure 1 here)

Although vaccine hesitancy depends on various factors, Lithuania's sociohistorical context stemming from the Soviet era may be important. According to Hoch (1997), the ability to control infectious diseases in the Soviet Union was perceived as an indicator of state superiority, resulting in strong-arm governmental programs flanked by health campaigns emphasizing vaccines as a public good and economic benefit. This legacy may have an ambivalent influence on Lithuania: While it has a strong history of mandatory vaccination in Soviet times, Lithuanians have turned away from this historical phase in many ways by orienting towards civil liberties - potentially including those towards vaccination.

Therefore, the primary goal of this paper was to understand what Lithuanians think about vaccines and how their beliefs evolved over time. While several studies have surveyed vaccine-related perceptions in Lithuania, no study has integrated and reviewed them systematically. We have done so, focusing on Lithuanians' perceptions of the general importance of vaccination, their safety and effectiveness - i.e. core attitudinal factors that are known to be linked to vaccination behavior (Opel et al., 2011) and relate to the foundational narratives of the anti-vaccine movement which has questioned all of these dimensions (Smith, 2017). Additionally, we reviewed the most common sources of information about vaccines among Lithuanians, to identify communicative avenues on which the public including vaccination skeptics might be addressed.

\section{Methods}

As shown in Figure 2, data were collected in several steps: 1) a keyword search in scholarly publication databases and the World Wide Web; 2) cross-referencing of eligible records from Step 1 for identification of additional records. For 
60

61

62

63

64

the keyword search, we used the Vilnius University online library, which provides consolidated access to scholarly publications indexed in over 90 national and international databases such as Web of Science, Springer LINK or MEDLINE, as well as the Lithuanian Academic Electronic Library, a national open access repository of Lithuanian publications. Keywords used for the search are shown in figure 2 and detailed in Supplemental material. Records identified in Step 1 were initially screened by title, abstract and/or content to determine their suitability for further analysis. Records were included if they studied data related to public awareness, knowledge, attitudes, opinion and/or perception of vaccines in Lithuania. If this could not be determined based on title, abstract or a preliminary screening of the content, the full text was read (see Fig. 2 for detailed inclusion/exclusion criteria). The final number of studies included in this review was $n=14$.

(Insert Figure 2 here)

\section{Results}

All 14 studies included in this review were quantitative surveys (table 1). 11 focused on public attitudes towards children's vaccines, several vaccines (e.g. MMR and Flu) or vaccines in general; 3 focused on public attitudes towards flu vaccines (see Supplemental material for studies on the flu vaccine). All surveys were cross-sectional; i.e. no longitudinal data was available for Lithuania. Most studies done nationally did not use representative samples, limiting their generalizability, but as they still provide valuable insights, they were included in the review.

\section{(Insert Table 1 here)}

\section{Importance of vaccines}

The earliest survey on Lithuanians' perceptions of vaccines was conducted in 2003/2004 with inhabitants of Lithuanian capital city Vilnius (Žagminas et al., 2007; table 1). It showed that a large majority (89\%) respondents agreed on the necessity of children's vaccines and a similar proportion (88.6\%) believed that children should be vaccinated according to the recommended immunization schedule. The first nationally representative survey was carried out in 2011 . In contrast to the first study, it demonstrated that nationally, only 54\% supported the use of vaccines for preventing infectious diseases and that 32\% expressed negative views towards their use (Baltijos tyrimai, 2011, Čaplinskas et al., 2011). In 2013 (Kuprevičienè et al., 2014), a second nationally representative study was conducted on Lithuanians' intention to vaccinate against flu, diphtheria and tetanus. It found that only $49.8 \%$ of respondents had positive attitudes towards vaccination for diphtheria and tetanus, which is given to adults but routinely also to children. 
Over the next five years, perceptions of vaccine importance were analyzed in several small-scale studies. Šeškutė et al. (2018) found that the overall opinion of post-partum mothers on children's vaccines in Kaunas was positive (83.2\%). Lidžiūtė and Stasiuvienè (2015) surveyed parents in Klaipèda, the third biggest city in Lithuania, in which $97.3 \%$ of respondents said vaccination was important for their children, but only $74.2 \%$ of respondents in the survey thought that children should be immunized according to the recommended schedule. In 2015, Kriščiūnienè et al. (2016) surveyed inhabitants of Tauragè and its surrounding district - a peripheral Lithuanian town with some 40,000 inhabitants. The sample was representative for the town's population. The survey did not measure attitudes towards vaccine importance directly, but revealed variances in vaccine perceptions between demographic groups: almost every second resident (53\%) believed most Lithuanians were skeptical about vaccination, particularly rural residents. In 2016 , Nevuliene et al. (2018) conducted an online survey with 425 respondents and while the survey once again did not measure perceptions of vaccine importance directly, it found that $17.4 \%$ of respondents believed that diseases for which vaccines are used have been eradicated, rendering vaccines for children unimportant $(70.1 \%$ of respondents disagreed with the statement).

Since then, three internationally comparative, representative surveys have examined Lithuanians' perceptions of vaccines. An online survey conducted for the EU Vaccine Confidence Project in May 2018 revealed that between 2011 and 2018, perceptions of vaccines in Lithuania improved considerably, with roughly $87 \%$ of respondents agreeing that vaccines were important for children. The general importance of vaccines and the importance of specific vaccines were rated differently; while $87 \%$ of respondents perceived vaccines to be generally important, only $50 \%$ found vaccines against seasonal influenza important.

Surprisingly, a second nationally representative survey carried out six months later - conducted with a different method, using face-to-face interviews but also asking for the importance of vaccinating children - showed a sharp decrease in perceived vaccination importance (figure 2). Compared to $87 \%$ of Lithuanians in May of 2018, only $69 \%$ in October agreed that vaccines for children were important (Wellcome Global Monitor, 2019).

\section{(Insert figure 3 here)}

In March of 2019 - after another half-year interval, again using face-to-face interviews, but this time asking about vaccination for both children and adults - the Eurobarometer showed that $87 \%$ of Lithuanians thought that "it is important for everyone to have routine vaccinations". The interpretation of these varying results is difficult, as sampling methods and survey questions differed, and as Lithuania experienced the largest measles outbreak of the last decade right after the second survey $(2019, \mathrm{~N}=834)$, potentially influencing the Eurobarometer results. 
Ten studies analyzed what Lithuanians think about vaccine effectiveness. With the exception of one survey (see Baltijos tyrimai (2011) in Table 1), results indicate different perceptions of vaccine importance vs. perceptions of effectiveness across all surveys and the entirety of the country. While vaccine importance is generally seen as high, evaluations of vaccine effectiveness are more critical.

Žagminas et al. (2007) found that in 2003/2004, only $62.7 \%$ of Vilnius inhabitants thought that vaccines are more effective and less expensive compared to other medical services. Furthermore, only a little more than a third of respondents (35.9\%) believed that children's vaccines always protect against infectious diseases. A 2011 survey showed that $67 \%$ of Lithuanian believed that vaccines are effective, but only in cases of a few diseases. However, only $60 \%$ of respondents in the same survey agreed with the general statement that vaccines are an effective means of protection against diseases and as much as $53 \%$ of respondents thought that effectiveness of vaccines is questionable, indicating that respondents are undecided about vaccine effectiveness or that perceptions of effectiveness may vary depending on particular vaccines/diseases (Baltijos tyrimai, 2011). A nationally representative study conducted by Kuprevičienè and Žagminas (2014) contained statements about diphtheria, tetanus and flu vaccines which can be seen as indirect measurements of attitudes to vaccine effectiveness (i.e. “vaccines are a good thing... because I don't have to worry about getting sick", "vaccines reduce the probability of getting sick") to which only $42.7 \%$ of respondents agreed.

In 2014 vaccines' perceived effectiveness was measured among postpartum mothers in a Kaunas hospital, which showed that 57.3\% saw vaccines as effective (Šeškutė et al., 2018). A study among Klaipeda parents at roughly the same time came to similar findings (54\%-60.6\%) (Lidžiūtè and Stasiuvienè, 2015), while an online survey a year later showed that $63.3 \%$ of respondents believed that vaccines prevent the spread of infectious diseases (Nevulienè et al., 2018). In contrast, a representative online survey from May 2018 showed that public confidence in vaccine effectiveness was at $81.4 \%$ (Vaccine Confidence Project, 2018). This positive, but rather contradictory result compared to other studies may indicate a bias stemming from the sampling techniques or indicate a spike in vaccine trust. In either case, public enthusiasm regarding vaccine effectiveness was brief: In October 2018, only 60\% of Lithuanians indicated that vaccines are effective (Wellcome Global Monitor, 2019). Similar to perceptions of vaccine importance, perceptions of vaccine effectiveness were most positive again in April 2019, reaching an all-time high $83 \%$ of the population (European Commission, 2019) - which may once again reflect the volatility of public opinion or public health alarmism in the aftermath of the large measles outbreak in 2019. Overall, results suggest that 20 to 40 percent of Lithuanians are and have been - doubtful about the effectiveness of vaccines. 
Vaccine safety has been one of the most hotly debated issues among vaccination skeptics. Nine studies between 2003 and 2020 analyzed Lithuanians' perceptions of vaccine safety, finding results similar to those regarding vaccine effectiveness. Žagminas et al. (2007) found that two-thirds (66.7\%) of Vilnius’ inhabitants believed vaccines were safe in 2003/2004. The 2011 nationally representative survey did not contain an item on vaccine safety perceptions, but found that $50 \%$ of Lithuanians believed the risks of adverse effects from vaccines outweighed their benefits (Baltijos tyrimai, 2011). In 2014 Šeškutė et al. (2018) found that $85.3 \%$ of surveyed post-partum mothers worried about vaccinating their child with $72.7 \%$ of these respondents worrying about possible adverse effects. In sum, only $57 \%$ of postpartum mothers in Kaunas believed in vaccine safety. Respondents of Lidžiūtè and Stasiuvienè (2015) were asked a double-barreled question - "I believe that vaccines are safe and effective" - making it difficult to differentiate between safety and effectiveness; nevertheless, only $60 \%$ agreed with the statement. In a 2016 online survey $32 \%$ of respondents believed vaccines were unsafe (58.4\% disagreed with the statement) and $42.4 \%$ of respondents believed that vaccines contain toxic ingredients. A subsequent, nationally representative survey found that $81.0 \%$ of Lithuanians believed in vaccine safety and a similar number of Lithuanians (78.0\%) believed in the safety of the MMR vaccine routinely given to children (Vaccine Confidence Project, 2018). As with the perceptions of vaccine effectiveness, this rather contradictory result compared to findings of previously conducted studies measuring vaccine safety may reflect biases stemming from previous non-representative samples or an overall spike in vaccine trust in May 2018. A survey conducted in October of 2018, however, differed, with only 52\% of Lithuanians believing in vaccine safety (Wellcome Global Monitor, 2019). Although the 2019 Eurobarometer did not ask explicitly about vaccine safety, it revealed that $55 \%$ believed that vaccines can "produce serious side effects" (European Commission, 2019). In sum, these studies outline a divided public. Surveys show consistently that more than one third of Lithuanians are unsure about vaccine safety.

\section{Information sources}

Apart from attitudes towards vaccines, several surveys analyzed the sources from which Lithuanians get information about vaccines: All surveys including this item found that doctors are the most common source of such information. Predictably, surveys measuring the trustworthiness of sources corroborate these findings: doctors are the most trustworthy source among Lithuanians (i.e. Baltijos tyrimai, 2011; European Commission, 2019). Other common sources of information include the Internet, mass media and friends or family, who commonly advise respondents on vaccines.

The reliance on friends and family as sources illustrates the strong effect of personal networks that are known to influence vaccine hesitancy (WHO, 2014). In Lithuania, this is especially evident in small communities like Tauragè, 
177

178

179

180

181

182

183

184

185

186

187

188

189

190

191

192

193

194

195

196

197

198

199

200

201

202

203

204

205

where a 2015 survey revealed that among those who did not vaccinate their children, almost $52 \%$ indicated advice from family and friends as a primary determinant for skipping vaccination (Kriščiūnienė et al., 2016).

Despite using various sources, $27 \%$ of Lithuanians indicated in 2011 that they felt not sufficiently informed about vaccines (Baltijos tyrimai, 2011), and 68.8\% expressed the necessity for more trustworthy information in 2014 (Šeškutė et al., 2018). It may be the case that these variations indicate a rising need for more dependable information about vaccination, stemming from the changing media systems and the increasing prevalence of content of problematic quality around science, technology and health issues (Schäfer, 2017). In sum, results show that Lithuanians do not feel sufficiently knowledgeable about vaccines and would prefer more information. Apart from health care professionals, they refer to a variety of sources such as mass media, Internet and relatives for information about vaccines, but trust doctors for the most accurate information.

How do Lithuanians' perceptions of vaccines compare to other countries?

Three studies included in this review are cross-national, allowing comparisons of Lithuanians' perceptions to other countries (Vaccine Confidence Project, 2018; Wellcome Global Monitor, 2019; European Commission, 2019). A panEuropean survey conducted in May 2018 showed that Lithuanians' perceptions of vaccine importance (87.0\%) was among the lowest in the EU (average $90.0 \%$ ), placing Lithuania $23^{\text {rd }}$ out of $28 \mathrm{EU}$ countries on the vaccine importance rating (Vaccine Confidence Project, 2018). Lithuania’s ranking (23) was slightly below Belgium (22) and above France (24), which has been a European hot-spot of anti-vaccine activism (Ward et al., 2018). Lithuania was also among the EU countries with the lowest confidence in vaccine effectiveness (24th out of 28 countries). On vaccine safety, Lithuania ranked $17^{\text {th }}$, between Estonia, Romania and Slovenia, which have all since 2010 experienced declining rates of measles vaccination.

The 2018 Wellcome Global Monitor (2019) revealed that on questions of safety, Lithuanians (52\%) deviate from Northern Europe, where vaccine safety perceptions lie around 73\%, as well as the world average perceptions about the safety of vaccines (79\%). This places Lithuanians on par with countries in Eastern Europe (50\%, most of which have observed declining vaccine rates over the past decades) and far behind countries in Eastern Africa (92\%), Central America and Mexico (88\%) and South Asia (95\%) which are highly confident in vaccine safety. On questions of effectiveness, Lithuanians (60\%) are again closer to Eastern European countries (65\%) than to Northern Europe (84\%), and below the world average ( $84 \%)$.

The 2019 Special Eurobarometer showed Lithuanians' perception of vaccine safety (only 32\% thought correctly that vaccines do not produce serious side effects) to be well below EU average (41\%), and that of neighbor countries, like Poland (45\%) (European Commission, 2019). Lithuanians (87\%), however, were above the EU average (82\%) on 
question of vaccine importance, surpassing countries like Germany (86\%) and the UK (85\%). It seems like the measles outbreaks in early 2019 considerably affected Lithuanians' attitudes towards vaccination.

209

210

211

212

213

214

215

216

217

218

219

220

221

222

223

224

225

226

227

228

\section{Discussion}

Scholars from various disciplines have highlighted the importance of public attitudes towards vaccines, as it may lead to suboptimal vaccine uptake (Larson et al., 2016). The present study reviewed public perceptions towards vaccines and their development in Lithuania, which in 2019 faced one of the highest rates of measles cases among European countries (ECDC, 2019). 14 studies were included, ten domestic and four international projects (see Supplemental material). All were based on standardized population surveys, but most used different methodologies and differently worded questions, hindering comparability. In addition, not all used representative samples. Overall, this signals the need for more representative, and ideally longitudinal research in this area.

The review showed that, first, perceptions of vaccines vary among regions. Three studies conducted within a comparatively similar period showed some variation in perceptions of vaccine importance among parents who lived in three distinct regions of Lithuania (Kaunas, Klaipeda and Tauragè), and - in one of the surveys - among respondents who lived in urban and rural areas (Lidžiūtè and Stasiuvienė, 2015; Kriščiūnienè et al., 2016; Šeškutè et al., 2018). This highlights that vaccine-related attitudes should not only be assessed at national but local level as well, and that urbanrural differences should be monitored closely. Such monitoring could help foresee the emergence of skeptical groups and may allow for corresponding public health measures (Kennedy et al., 2011).

Second, results suggest that perceptions of vaccination differ between individual vaccines. Multiple survey have shown Lithuanians to be critical about the flu vaccine (Vaccine Confidence Project, 2018; Kuprevičienè and Žagminas, 2014). Compared to perceptions of vaccination in general or MMR vaccine, respondents were less positive about the safety and effectiveness of flu vaccines (Vaccine Confidence Project, 2018).

Third, the results suggest changes over time. The studies using representative data over the past 15 years show that perceptions of vaccine importance in Lithuania were low twice - likely between 2011-2013 and in October of 2018 (Baltijos tyrimai, 2011; Čaplinskas et al., 2011; Kuprevičiene and Žagminas, 2014; Wellcome Global Monitor, 2019). At the end of 2018, almost a third of Lithuanians were skeptical about the importance of children's vaccines. Soon after, Lithuania experienced a large measles outbreak, which improved attitudes towards vaccination again. This suggests that public attitudes may be a key factor shaping public health crises, and that public opinion tracking may help foresee disease outbreaks. The fluctuation of public opinion in the brief period between May 2018 and March 2019 also suggests that Lithuanians' attitudes towards vaccines can be volatile. While some researchers may attribute such cases 
of variance to errors of measurement, others argue they reveal more about the underlying nature of public opinion and how people think (Converse, 1964).

A fourth significant finding is a considerable discrepancy between Lithuanians' views towards the importance of vaccines and their perceptions of effectiveness and safety. While Lithuanians' beliefs about vaccine importance are positive, their perceptions of effectiveness and safety are more cautious. Except for May 2018, public evaluations of vaccine safety ranged from $52 \%$ to $66.7 \%$, meaning that at least every 3 out of 10 people had doubts about the safety of vaccination (table 1). Perceptions of vaccine effectiveness were relatively similar: except for March 2019 perceptions of effectiveness ranged from $63.3 \% 35.9 \%$ to $60.0 \%$ (table 1 ). This discrepancy may suggest that even those who understand the benefits of vaccines may be prone to delaying or refusing children's immunization. These findings also demonstrate that positive perceptions of vaccine importance may not guarantee high vaccination rates.

Overall, these findings have implications for public health interventions and communication about vaccines. First, they provide a clearer picture of vaccine perceptions in Lithuania, suggesting that Lithuanians may not be "anti-vaccine", but hesitant about vaccination. In terms of public health literature, they could be called the "fence-sitters" - not entirely rejecting vaccines, but worried about their impact (Rossen et al., 2019; Betsch et al., 2015). Second, the findings have implications for public health politics and health communication: They suggest that different vaccines are perceived differently, requiring different communication strategies. For example, this overview has pinpointed specific vaccinerelated concerns among Lithuanians, which could be used to target vaccine related communication towards public views. If public health messages in Lithuania focus on vaccine importance instead of evidence on their safety, for example, they may fail to address Lithuanians' core concerns. Future studies should explore and better tailor effective messaging and communication.

Finally, there is an implication for research politics: The amount of representative research on Lithuanians' attitudes towards vaccination is limited, and the existing studies use different methods and are hard to compare. Representative surveys using standardized instruments to measure the Lithuanian population's perceptions of vaccination, done regularly, would provide both an evidence base for preemptive public health measures and be a valuable tool for scholarly research.

The authors have no conflicts of interest to disclose.

\section{References}

Betsch C, Korn L, Holtmann C (2015) Target fence-sitters not antivaccinators, PNAS 112 (49): E6725-E6726.

Baltijos tyrimai (2011) Vakcinos. Lietuvos gyventojų nuostatos ir patirtis. http://www.ulac.lt/uploads/downloads/alisauskienes\%20pr.pdf. Accessed on 5 March 2020. 
Converse P (1964) The nature of belief system in mass publics. In: Apter D (ed) Ideology and discontent, New York, Free Press, pp 206-261.

Dubé E, Laberge C, Guay M, Bramadat P, Roy R, Bettinger J (2013) Vaccine hesitancy: an overview. Hum Vaccin Immunother 9 (8): 1763-1773.

European Center for Disease Prevention and Control (2019) Monthly measles and rubella monitoring, August 2019. https://ecdc.europa.eu/sites/portal/files/documents/measles-monthly-report-august-2019.pdf. Accessed on 15 August 2019.

European Commission (2019) Europeans' attitudes towards vaccination. file:///C:/Users/1032211/Downloads/ebs_488_sum_en\%20(3).pdf. Accessed on 30 June 2019.

Eurostat (2018) Educational attainment statistics. https://ec.europa.eu/eurostat/statisticsexplained/index.php/Educational_attainment_statistics. Accessed on 5 October 2019.

Hoch SL (1997) The social consequences of soviet immunization policies, 1945-1980. https://www.ucis.pitt.edu/nceeer/1997-812-03g-Hoch.pdf. Accessed on 5 October 2019.

Kennedy, AE, LaVail KH, Nowak GJ, Basket MM, Landry SJ (2011) Confidence about vaccines in the United States: understanding parents' perceptions. Health Aff 30 (6): 1151-1159.

Kriščiūnienė A, Jurgutis A, Jurgaitienė D, Strukčinskienė B (2016) Miesto ir kaimo gyventojų požiūris ị skiepus. Visuomenès sveikata 2: 106-112.

Kuprevičienè N, Žagminas K (2014) Lietuvos suaugusių gyventojų ketinimas skiepytis ir jị lemiantys veiksniai. Visuomenès sveikata 66: 56-67.

Lane S, MacDonald NE, Marti M, Dumolard L (2018) Vaccine hesitancy around the globe. Vaccine 36(26): 38613867.

Larson H J, de Figueiredo A, Xiahong Z, Schulz WS, Verger P, Johnston IG, Jones NS (2016) The state of vaccine confidence 2016. EBioMedicine 12: 295-301.

Lidžiūtė L, Stasiuvienė D (2015) Tẻvų, kurių vaikai lanko lopšelị, informuotumas apie vakcinas ir jų požiūris ị vaikų imunoprofilaktiką. Visuomenès sveikata 1: 102-109.

Nevulienė I, Platūkienė A, Samoškienė K, Valinskytė M, Vasiliauskienė O (2018) Vaikų imunoprofilaktika: tėvų žinios, požiūris, veiksniai lemiantys vaikų skiepijimą. Lietuvos bendrosios praktikos gydytojas 22 (8): 517-521.

OECD (2018) Economic surveys, Lithuania, 2018 June. https://www.oecd.org/eco/surveys/Lithuania-2018-OECDeconomic-survey-overview.pdf. Accessed on 5 October 2019.

OECD (2018) OECD reviews of health systems: Lithuania 2018. https://www.oecd.org/health/health-systems/OECDReviews-of-Health-Systems-Lithuania-2018-Assessment-and-Recommendations.pdf. Accessed on 5 October 2019.

Opel DJ, Mangione-Smith R, Taylor JA, Korfiatis C, Wiese C, Catz S, Martin DP (2011) Development of a survey to identify vaccine-hesitant parents. Hum Vaccin 7(4): 419-425.

Orenstein WA, Ahmed R (2017) Simply put: vaccination saves lives. PNAS 114(16): 4031-4033.

Rossen I, Hursltone MJ, Dunlop PD, Lawrence C (2019) Accepters, fence sitters, or rejecters: Moral profiles of vaccination attitudes. Soc Sci Med, 224: 23-27.

Šebeliauskaitė I., Čaplinskas S (2018) Vaikų skiepijimo apimčių tendencijos Lietuvoje, 2003-2017. 6-oji Nacionalinė užkrečiamųjų ligų konferencija: 2018 m. lapkričio 29-30.

http://www.ulac.lt/uploads/downloads/konferencijos/Teziu_knyga_nuk_18.pdf. Accessed on 3 September 2019.

Schäfer MS (2017) How changing media structures are affecting science news coverage. In: Jamieson, K. H., Kahan, D.M., Scheufele, D.A. (eds) The Oxford Handbook of the Science of Science Communication, Oxford University Press, pp. 51-57. 
Smith TC (2017) Vaccine rejection and hesitancy: a review and call to action. Open Forum Infect Dis, 4 (3).

Šeškutė M, Tamulevičienė E, Levinienė G (2018) Knowledge and attitudes of postpartum mothers towards immunization of their children in a Lithuanian tertiary teaching hospital, Medicina 54 (1): 2.

Thornton, J (2019) Measles cases in Europe tripled from 2017 to 2018. BMJ, 364 (1634).

United Nations Development Program. Human development reports, 2018. Available at: http://hdr.undp.org/en/countries/profiles/LTU Accessed on 5 October 2019.

Užkrečiamų ligų prevencijos ir AIDS centras (2019) Patvirtinta nacionalinė 2019-2023 metų imunoprofilaktikos programa, 201902 19. http://www.ulac.lt/naujienos/pranesimai-spaudai/patvirtinta-nacionaline-20192023-metuimunoprofilaktikos-programa. Accessed on 5 October 2019.

Užkrečiamų ligų prevencijos ir AIDS centras (a). Tymų epidemiologinė apžvalga Lietuvoje. http://www.ulac.lt/lt/tymuepidemiologine-apzvalga-lietuvoje. Accessed on 30 September 302019.

Užkrečiamų ligų prevencijos ir AIDS centras (b). Tymų žemėlapis Lietuvoje. http://www.ulac.lt/lt/tymu-zemelapislietuvoje-2019. Accessed on 30 September 2019.

Vaccine Confidence Project (2018) State of vaccine confidence in the EU 2018. https://ec.europa.eu/health/sites/health/files/vaccination/docs/2018_vaccine_confidence_en.pdf. Accessed on 5 May 2019.

Ward, JK, Colgrove J, Verger P (2018) Why France is making eight new vaccines mandatory. Vaccine 36 (14): 1801 1803.

Wellcome Global Monitor (2019) How does the world feel about science and health? file:///C:/Users/1032211/Downloads/wellcome-global-monitor-2018\%20(1).pdf. Accessed on 30 June 2019.

World Health Organization (2019) New measles surveillance data from WHO, 2019 August 12.

https://www.who.int/immunization/newsroom/new-measles-data-august-2019/en/. Accessed on 28 September 2019.

World Health Organization (2014) Report of the SAGE working group on vaccine hesitancy. https://www.who.int/immunization/sage/meetings/2014/october/1_Report_WORKING_GROUP_vaccine hesitancy_fi nal.pdf. Accessed on 20 May 2019.

Yaqub OJ, Castle-Clarke S, Sevdalis N, Chataway J (2014) Attitudes to vaccination: a critical review. Soc Sci Med, 112: 1-11.

Žagminas K, Šurkienė G, Urbanovič N, Stukas R (2007) Parental attitudes towards children's vaccination. Medicina, 43(2): 161-169.

\section{Table and figure captions}

\section{Figure 1}

Figure 1. Measles cases in Lithuania in 2008-2019, official statistical data from the Center for Communicable Disease and AIDS in Lithuania (Užkrečiamų ligų ir AIDS centras) (ULAC a).

Figure 2 Data collection flowchart 
383 Table 1 Research studies analyzing public perceptions of vaccines in Lithuania (survey questionnaire items 384 presented in original and translated formulations)

385 Figure 3 Results of representative surveys on Lithuanian public perceptions towards the importance,

386 effectiveness and safety of vaccines $(\%)$ and years of recent measles cases/outbreaks occurrence in Lithuania

387 